\section{ECONOMICS}

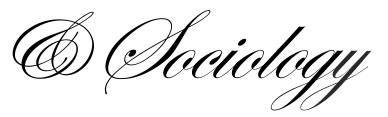

Namiotko, V., Galnaitytė, A., Baležentis, T., \& Wang, P. (2019). The impact of investment support on labour productivity in Lithuanian family farms: A propensity score matching approach. Economics and Sociology, 12(1), 342-352. doi:10.14254/2071-789X.2019/12-1/21

\title{
THE IMPACT OF INVESTMENT SUPPORT ON LABOUR PRODUCTIVITY IN LITHUANIAN FAMILY FARMS: A PROPENSITY SCORE MATCHING APPROACH
}

Virginia Namiotko,

Lithuanian Institute of Agrarian

Economics,

Vilnius, Lithuania,

E-mail:virginia@laei.lt

\author{
Aistè Galnaitytè, \\ Lithuanian Institute of Agrarian \\ Economics, \\ Vilnius, Lithuania, \\ E-mail:aiste@laei.lt \\ Tomas Baležentis, \\ Lithuanian Institute of Agrarian \\ Economics, \\ Vilnius, Lithuania, \\ E-mail:tomas@laei.lt \\ Peng Wang, \\ Chongqing Business Vocational \\ College, \\ Chongqing, China \\ E-mail:peng.1122@foxmail.com
}

Received: October, 2018

1st Revision: December, 2018

Accepted: March, 2019

DOI: $10.14254 / 2071-$

789X.2019/12-1/21

JEL Classification: C21, Q12, Q18
ABSTRACT. The aim of this paper is to assess the impact of investment support on labour productivity in Lithuanian family farms. This issue is of particular importance when appraising whether the investment support has had the anticipated effects. Propensity score matching is employed to quantify the average treatment effect on the treated farms. The research is based on panel data from the Farm Accountancy Data Network covering the period of 20072012. The results show that Lithuanian farmers' participation in investment measures did not result in labour productivity gains. These results provide guidance for policy makers with regards to decisions on investment support measures beyond 2020 .

Keywords: investment support, labour productivity, Lithuania, family farms, propensity score matching. 


\section{Introduction}

Investment support aimed at increasing farms' productivity is one of the most important measures within the European Union (EU) Member States' rural development programmes (Ciaian et al., 2015). The effects of investment support, therefore, have attracted considerable academic interest in recent years. For instance, Buysse et al. (2011), after analyzing the effects of different kinds of support measures, concluded that investment support contributed to output and therefore to income growth in Belgian agriculture. Kollár and Sojková (2016) revealed that investment subsidies significantly affected the efficiency of farms in Slovakia. Pechrova (2012) showed that investment support helped Czech farmers to adopt new technologies and innovations.

A closer look at the literature on the effects of investment support, however, reveals that such support along with positive effects causes a variety of negative processes. Ciaian et al. (2015) found that investment support resulted in growth of prices for the resources used in farm production. Veveris (2014) and Ratinger et al. (2015) observed that such support also widened the gap between small and large farms - in most cases investment support was used by large farms, while small farms did not participate in investment measures due to complicated administrative procedures, co-financing requirements, lack of entrepreneurship skills etc. Wigier et al. and Papageorgiou (2015) showed that investment subsidies very often stimulated excessive investment.

When analyzing scientific literature on the impact of investment support on labour productivity, it can be seen that previous studies do not provide a clear, unambiguous answer to this question, and some even contradict each other. Hlavsa et al. (2017) evaluated investment activities of farms in the Czech Less Favoured Areas (LFAs), as compared to those in non-LFAs. They demonstrated that farms receiving investment subsidies had higher labour productivity than unsubsidized farms. Similarly, Medonos et al. (2012) and Ratinger et al. (2013) found that investment support measures improved labour productivity in Czech Republic, however, this effect varied significantly between different farm types, farming conditions and farm sizes. Moreover, in another study, Ratinger et al. (2018) demonstrated that the impact of investment support on labour productivity was positive only in the period of 2008-2011.

Takács (2014) examined changes in labour productivity in Hungary and Poland in the context of all other EU member states. He found that, during the research period, labour productivity in Hungarian farms increased, while at the same time Hungarian farms' investment lagged behind farms' investment in the old EU Member States. On the other hand, Polish farms' investment were higher than in the EU-15 countries, while labour productivity was still far behind the leading EU member states. However, Pawłowska et al. (2018) showed that in recent years labour productivity in Polish farms increased due to investment support.

Kirschweger et al. (2015), after analyzing the impact of investment support on economic performance of Austrian farms, concluded there was a positive effect of investment support on labour productivity. Travnikar and Juvančič (2013) arrived at the same conclusions after analyzing the impacts of investment support on farms in Slovenia, whereas Bartova and Hurnakova (2016) obtained essentially the same results for Slovak farms. However, Salvioni and Sciulli (2018) observed a different pattern for Italian farms as investment support did not lead to a growth in their labour productivity. According to these researchers, the main reason for this was short post-intervention period.

Currently, assessment of the effects of investment support is particularly important. This is mainly due to the initiated EU-wide debate on the Common Agricultural Policy (CAP) priorities and development needs beyond 2020 and the necessity of using the EU support effectively and creating the highest possible European value added. In this context, this paper 
aims to assess the impact of investment support on labour productivity in Lithuanian family farms. The following tasks are therefore set: 1) to present the framework for the assessment of the impact of investment support on labour productivity; 2) to reveal the main trends in investment activity and labour productivity in Lithuanian family farms; 3) to identify the effect of participation in investment measures on labour productivity in Lithuanian family farms.

The article is organised as follows. Section 1 introduces a methodological approach for assessment of the impact of investment support on labour productivity. Section 2 presents the results and discusses avenues for further research. The final part presents research conclusions.

\section{Methodological approach}

The research seeks to assess the impact of investment support on labour productivity in Lithuanian family farms. Therefore, drawing on previous research (e.g., Medonos et al., 2012; Kirchweger et al., 2015), propensity score matching is employed.

In order to estimate the propensity scores for each farm, we applied binary logistic regression, also called a logit model:

$$
L_{i}=\ln \left(\frac{P_{i}}{1-P_{i}}\right)=\beta_{0}+\sum_{j=1}^{m} \beta_{i} X_{i j}
$$

where $P$ represents the probability of an event occurring, $X$ denotes the independent variables, $\beta$ stands for the regression coefficients.

From a review of the literature, 9 variables were selected as factors affecting farmers' participation in investment measures: farmer's age (in years), total assets (in EUR), total labour input (in AWU), total liabilities (in EUR), total livestock units (in LU), net investment (in EUR), dummy variable for organic farming, income from sources other than farming (in EUR), and total subsidies (excluding on investment) (in EUR). There was no multicollinearity among the independent variables. Therefore, all these variables were incorporated in the model.

Although there are many algorithms to pair treated and control units (Strawiński, 2014), we used the most frequently applied technique, i.e., nearest neighbour matching, which selects for each treated unit $i$ the control unit based on the closest distance between their propensity scores. Through these two steps, pairs consisting of one treated and one control unit were built and the control group which is identical to the treated group was generated.

Propensity score matching requires that two assumptions be met. The first assumption is the conditional independence assumption, which states that the potential outcome is independent of the treatment assignment (Guo, \& Fraser, 2015):

$$
\left(Y_{0 i}, Y_{1 i}\right) \perp\left(D_{i} \mid \mathbb{x}_{i}\right)
$$

where $Y_{1 i}$ denotes the outcome if the $i^{\text {th }}$ unit was treated, $Y_{0 i}$ represents the outcome if the $i^{\text {th }}$ unit was not treated, $D_{i}$ stands for a binary variable that equals 1 if the $i^{\text {th }}$ unit was treated or 0 otherwise, $\mathbb{x}_{i}$ indicates a vector of observed characteristics for the $i^{\text {th }}$ unit.

The second assumption that is required for matching is the overlap assumption, which means that there is overlap in the covariate distributions between the treated and control groups: 


$$
0<P\left(D_{i}=1 \mid \mathbb{x}_{i}\right)<1
$$

After verifying these assumptions, it is possible to identify the average treatment effect on the treated (ATT). The ATT was computed as the difference in mean outcomes of the treated and controls (Pawłowska, Bocian, 2017):

$$
W_{A T T}=E\left(Y_{1 i}-Y_{0 i} \mid D_{i}=1\right)=E\left(Y_{1 i} \mid D_{i}=1\right)-E\left(Y_{0 i} \mid D_{i}=1\right) .
$$

As noted in the literature (e.g., Power, 1998), there is often a considerable lags between the timing of investment and its impact on farm productivity. Therefore, we follow Pawłowska and Bocian (2017) and assume that farms' characteristics in period $t$ affect the probability of participation in investment measures in period $t+1$ and labour productivity in period $t+2$. Based on prior research, we measured labour productivity as the total farm output per annual work unit (AWU) (in EUR/AWU).

The research was based on Farm Accountancy Data Network (FADN) dataset (Lithuanian Institute of Agrarian Economic, 2018). The analysis used a balanced panel for 2007-2012 covering family farms that received investment support as well as family farms that did not benefit from investment support. The panel consisted of 284 family farms. The period of analysis was determined by the availability of data (Fig. 1).

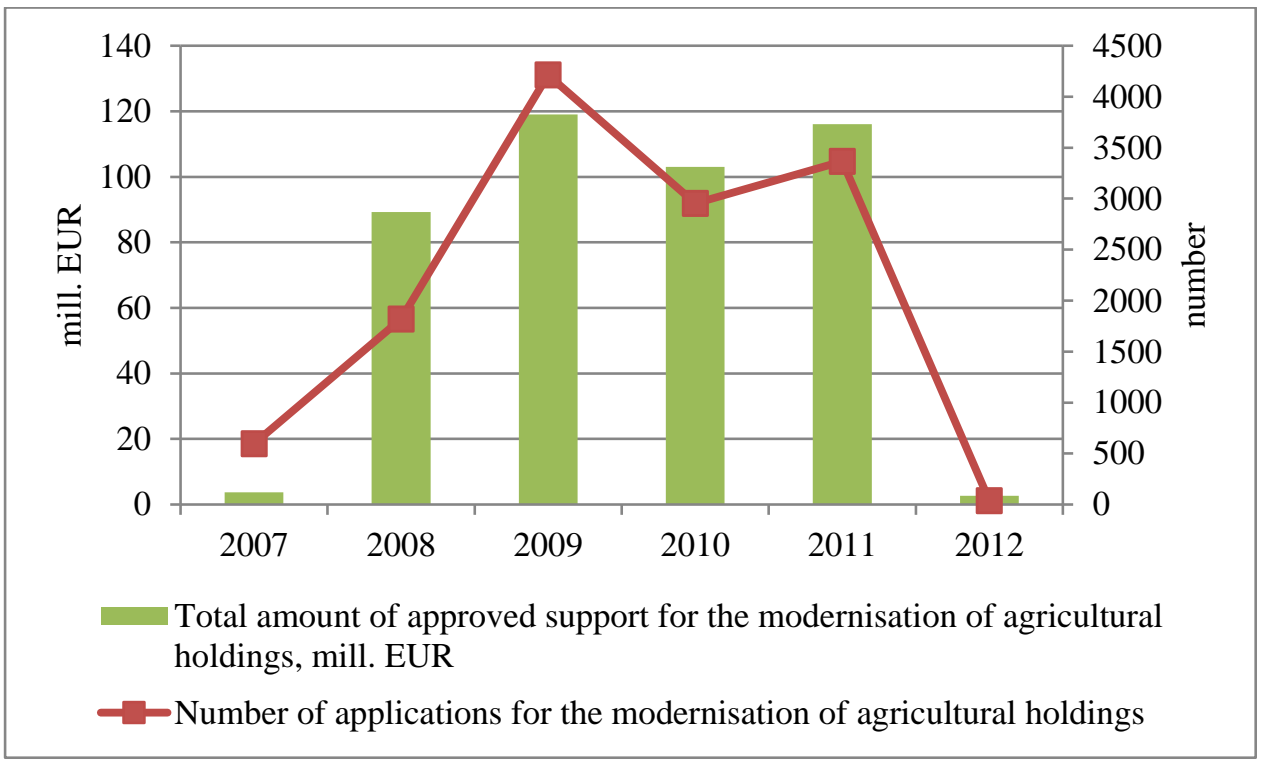

Figure 1. Number of applications for the modernisation of agricultural holdings and total amount of approved support for the modernisation of agricultural holdings in Lithuania, 2007-2012 (National Paying Agency, 2019)

Matching was performed in $\mathrm{R}$ using the Matching package.

\section{Results}

After Lithuania's accession to the EU in 2004, Lithuanian farmers started to receive substantial benefits from the CAP. Support payments under the CAP enabled farmers to actively invest in fixed assets. 
INTERDISCIPLINARY APPROACH TO ECONOMICS AND SOCIOLOGY

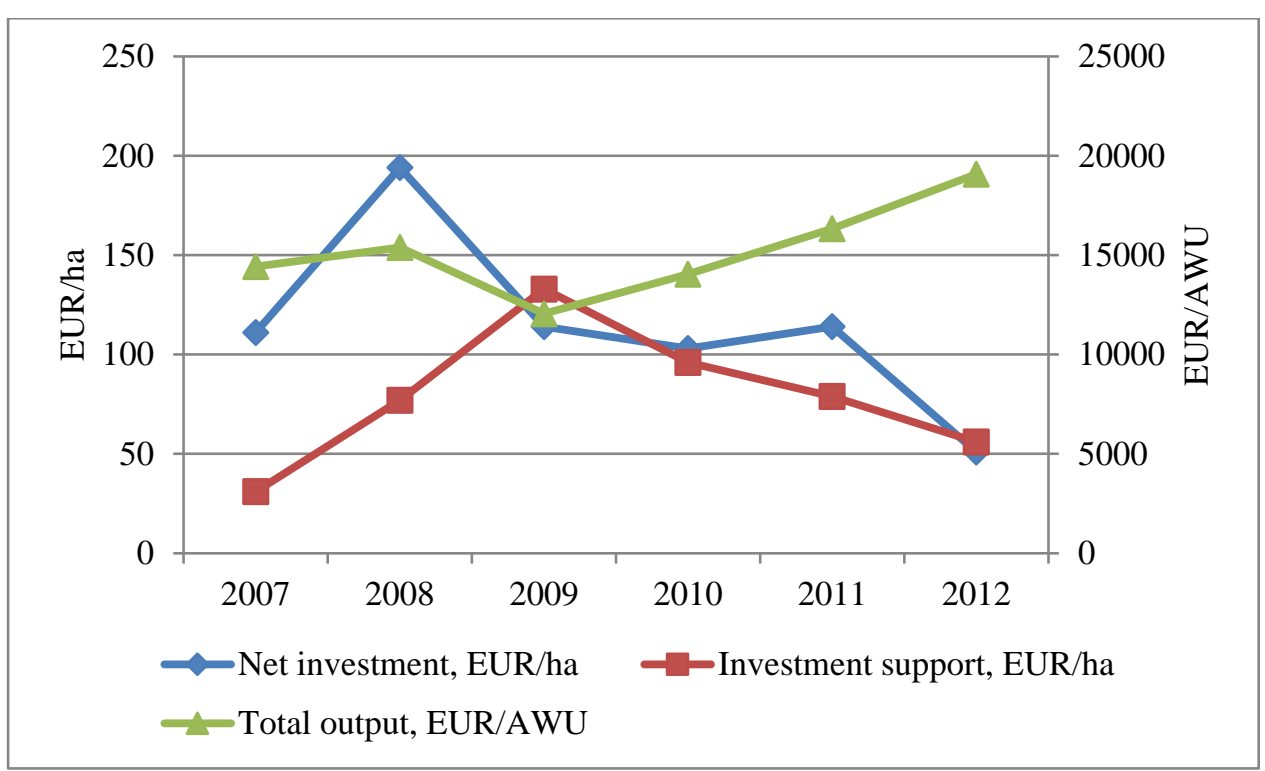

Figure 2. Net investment, support for investment and total output in Lithuanian family farms, 2007-2012 (Lithuanian Institute of Agrarian Economics, 2018)

More specifically, analysis of net investment in Lithuanian family farms shows that net investment in 2007-2012, on average, reached 115 EUR/ha. The lowest net investment was in 2012, whereas the highest net investment occurred in 2008. As can be seen in Fig. 2, the fall in net investment at the end of the period was mainly due to declining investment support. As regards the total output per AWU, it showed an upward trend during 2007-2012. This can be explained by both decreased labour input and increased total output.

In order to deliver insights into cross-country differences in family farms' investment activity and labour productivity, Table 1 presents the key investment and production indicators for farms in selected EU member states. As can be seen in this table, in 2007-2012, the lowest investment support was observed in Denmark and Germany. On the other hand, the highest investment support intensity was in Lithuania. The opposite pattern, however, was identified for fixed assets. In this case, the new EU member states, namely, Latvia and Lithuania, exhibited the lowest value of fixed assets, whereas Denmark and Germany featured the highest value of this indicator.

Table 1. Key investment and production indicators for farms in selected EU member states, averages for 2007-2012 (European Commission, 2018)

\begin{tabular}{lccccc}
\hline Country & $\begin{array}{c}\text { Investment } \\
\text { support, EUR/ha }\end{array}$ & $\begin{array}{c}\text { Net investment, } \\
\text { EUR/ha }\end{array}$ & $\begin{array}{c}\text { Machinery and } \\
\text { buildings, EUR/ha }\end{array}$ & $\begin{array}{c}\text { Total fixed } \\
\text { assets, EUR/ha }\end{array}$ & $\begin{array}{c}\text { Total output, } \\
\text { EUR/AWU }\end{array}$ \\
\hline Denmark & 2 & 363 & 5880 & 22906 & 219197 \\
\hline Germany & 5 & 95 & 2216 & 8006 & 96877 \\
\hline Latvia & 29 & 81 & 636 & 1075 & 21563 \\
\hline Lithuania & 79 & 115 & 1005 & 1510 & 18777 \\
\hline Poland & 12 & 0 & 2924 & 6033 & 15892 \\
\hline
\end{tabular}

As regards labour productivity, the lowest total output per AWU was achieved in Poland. At the other end of the spectrum, Denmark and Germany featured the highest values of total output per AWU. Therefore, it can be concluded that even labour productivity increased in the new EU member states, substantial cross-country differences persisted. 
INTERDISCIPLINARY APPROACH TO ECONOMICS AND SOCIOLOGY

Table 2. Descriptive statistics for variables used in the logistic regression analysis

\begin{tabular}{|c|c|c|c|c|}
\hline Variable & Mean & Standard Deviation & Minimum & Maximum \\
\hline Farmer's age, years & 46 & 11 & 20 & 85 \\
\hline Total assets, EUR & 317566 & 403966 & 5050 & 3434101 \\
\hline $\begin{array}{l}\text { Total labour input, } \\
\text { AWU }\end{array}$ & 3.5 & 3.2 & 0.9 & 29.4 \\
\hline $\begin{array}{l}\text { Total liabilities, } \\
\text { EUR }\end{array}$ & 103401 & 176914 & 0 & 1585494 \\
\hline $\begin{array}{ll}\text { Total livestock } \\
\text { units, LU }\end{array}$ & 35 & 69 & 0 & 567 \\
\hline $\begin{array}{l}\text { Net investment, } \\
\text { EUR }\end{array}$ & 33211 & 95617 & -285191 & 1067249 \\
\hline $\begin{array}{l}\text { Participation in } \\
\text { organic farming, } \\
\text { dummy }\end{array}$ & 0.9 & 0.3 & 0 & 1 \\
\hline $\begin{array}{lr}\text { Income } & \text { from } \\
\text { sources other than } \\
\text { farming, EUR }\end{array}$ & 3428 & 11712 & 0 & 129639 \\
\hline $\begin{array}{l}\text { Total subsidies } \\
\text { (excluding } \\
\text { investment), EUR }\end{array}$ & 33886 & 37420 & 240 & 299189 \\
\hline
\end{tabular}

Note: Descriptive statistics of the whole sample.

As noted earlier, from a review of the literature, 9 variables were selected as factors affecting farmers' participation in investment measures. Table 2 provides some descriptive statistics for all variables.

A closer look at these data indicates that the studied family farms had, on average, a large amount of total assets. The average value of total assets was 317566 EUR, whereas the maximum one reached 3434101 EUR. Also, it is interesting to note that the average net investment amounted to 33211 EUR. It should be noted, however, that some family farms had negative net investment.

Looking at the data in Table 3, one can notice certain differences between Lithuanian family farms receiving and not receiving investment support. During the research period, farms receiving investment support were, on average, larger in terms of utilized agricultural area than farms not receiving investment support. On the contrary, other indicators, such as capital intensity, differed in terms of magnitudes across the two groups of farms at the beginning and at the end of the research period.

As mentioned earlier, to estimate the propensity scores, a logistic regression model was used. As can be seen in Table 4, during the research period the probability of participation in investment measures was affected by various factors. For instance, at the beginning of research period the probability of participation in investment measures was higher among farms with a greater number of livestock units, while it was lower among farms that use more labour. In addition, participation in investment measures was more likely for pluriactive farms. This can be explained by the willingness of pluriactive farmers to substitute capital for labour. Finally, the probability of participation in investment measures was higher among farms that had a high initial net investment. This is mainly due to farmers' willingness to maintain high technological level. 
Table 3. Selected characteristics of Lithuanian family farms receiving and not receiving investment support

\begin{tabular}{|c|c|c|c|c|c|c|}
\hline \multirow[b]{2}{*}{ Variable } & \multicolumn{2}{|c|}{2007} & \multicolumn{2}{|c|}{2010} & \multicolumn{2}{|c|}{$\begin{array}{c}\text { Change } 2010, \text { compared to } \\
2007, \%\end{array}$} \\
\hline & $\begin{array}{c}\text { Farms } \\
\text { receiving } \\
\text { investment } \\
\text { support }\end{array}$ & $\begin{array}{l}\text { Farms not } \\
\text { receiving } \\
\text { investment } \\
\text { support } \\
\end{array}$ & $\begin{array}{c}\text { Farms } \\
\text { receiving } \\
\text { investment } \\
\text { support } \\
\end{array}$ & $\begin{array}{l}\text { Farms not } \\
\text { receiving } \\
\text { investment } \\
\text { support }\end{array}$ & $\begin{array}{c}\text { Farms } \\
\text { receiving } \\
\text { investment } \\
\text { support } \\
\end{array}$ & $\begin{array}{c}\text { Farms not } \\
\text { receiving } \\
\text { investment } \\
\text { support } \\
\end{array}$ \\
\hline $\begin{array}{l}\text { Total utilized } \\
\text { agricultural } \\
\text { area, hectares }\end{array}$ & 204.9 & 188.0 & 241.3 & 209.9 & 17.8 & 11.6 \\
\hline $\begin{array}{l}\text { Total labour } \\
\text { input, AWU }\end{array}$ & 3.1 & 3.3 & 4.2 & 3.4 & 35.5 & 3.0 \\
\hline $\begin{array}{l}\text { Number of } \\
\text { livestock units } \\
\text { per hectare of } \\
\text { UAA }\end{array}$ & 0.3 & 0.4 & 0.7 & 0.3 & 133.3 & -25.0 \\
\hline $\begin{array}{l}\text { Total assets } \\
\text { per hectare of } \\
\text { UAA, EUR }\end{array}$ & 1685 & 1913 & 3162 & 2115 & 87.7 & 10.6 \\
\hline $\begin{array}{l}\text { Total } \\
\text { liabilities per } \\
\text { hectare of } \\
\text { UAA, EUR }\end{array}$ & 394 & 409 & 481 & 342 & 22.1 & -16.4 \\
\hline
\end{tabular}

Table 4. Factors of farmers' participation in investment measures

\begin{tabular}{lcccc}
\hline \multicolumn{1}{c}{ Variable } & 2008 & 2009 & 2010 & 2011 \\
\hline Farmer's age & $-0.003(0.014)$ & $-0.018(0.013)$ & $-0.019(0.013)^{*}$ & $-0.021(0.016)$ \\
\hline Total assets & $0.000(0.000)$ & $0.000(0.000)$ & $0.000(0.000)$ & $0.000(0.000)$ \\
\hline Total labour input & $-0.240(0.109)^{* *}$ & $-0.029(0.068)$ & $0.069(0.058)$ & $-0.067(0.079)$ \\
\hline Total liabilities & $0.000(0.000)$ & $0.000(0.000)$ & $0.000(0.000)$ & $0.000(0.000)$ \\
\hline Total livestock units & $0.007(0.003)^{* * *}$ & $0.002(0.003)$ & $0.002(0.002)$ & $0.011(0.003)^{* * *}$ \\
\hline Net investment in & $0.000(0.000)^{*}$ & $0.000(0.000)^{* * *}$ & $0.000(0.000)^{*}$ & $0.000(0.000)^{*}$ \\
\hline $\begin{array}{l}\text { Participation } \\
\text { organic farming }\end{array}$ & $-0.344(0.460)$ & $-0.121(0.417)$ & $-0.038(0.423)$ & $-0.973(0.453)^{* *}$ \\
\hline $\begin{array}{l}\text { Income from sources } \\
\text { other than farming }\end{array}$ & $0.000(0.000)^{*}$ & $0.000(0.000)$ & $0.000(0.000)$ & $0.000(0.000)$ \\
\hline $\begin{array}{l}\text { Total subsidies } \\
\text { (excluding } \\
\text { investment) }\end{array}$ & $0.000(0.000)$ & $0.000(0.000)^{*}$ & $0.000(0.000)^{*}$ & $0.000(0.000)$ \\
\hline
\end{tabular}

Note: Cells contain binary logistic regression coefficients with standard errors in parentheses $\left({ }^{* * *} \mathrm{p}<0.01 ;{ }^{* *} \mathrm{p}<0.05 ;{ }^{*} \mathrm{p}<0.1\right)$.

Table 5 presents the results of ATT using nearest neighbour matching. As can be seen in this table, there was no any statistically significant effect of investment support on labour productivity in Lithuanian family farms. These findings, however, cannot be directly interpreted as evidence of ineffectiveness of investment support. One possible explanation for these findings is too short post-intervention period. For instance, such a case is described by Hugget and Ospina (2001) and Sakellaris (2004), who revealed that productivity improves only in the long run. Another reason for this may be that the research covered period of financial crisis, which changed farmers' investment behaviour and, thus, actual effects of investment support. On the other hand, however, based on the findings of earlier studies (e.g., Papageorgiou, 2015; Sass, 2017), it can be concluded that such results can also be caused by over-investment and inefficient use of capital. 
INTERDISCIPLINARY APPROACH TO ECONOMICS AND SOCIOLOGY

Table 5. Effect (ATT) of investment support on labour productivity (in EUR/AWU)

\begin{tabular}{lcccc}
\hline Parameter Estimates & 2009 & 2010 & 2011 & 2012 \\
\hline Estimate & 5549 & 5714 & 4982 & 5605 \\
\hline Standard Error & 296 & 360 & 316 & 911 \\
\hline$p$-value & $>0.05$ & $>0.05$ & $>0.05$ & $>0.05$ \\
\hline
\end{tabular}

Thus, these results provide some suggestions to policy makers with regards to decisions on investment support measures beyond 2020. The main conclusion emerging from this research is that current investment support measures based on a one-time subsidy should be replaced by other measures which do not encourage excessive investment (e.g., repayable investment support). Similar recommendations were offered by Polish and Czech researchers (e.g., Kulawik, 2016; Doucha et al., 2017). This research, however, leaves room for further investigation into this question. Future research could be firstly aimed at considering a longer time span. Another field of future research could be the assessment of the impact of investment support on other farm performance indicators. And finally, based on the findings from the literature (e.g., Rosenbaum, 2005; Kirchweger, Kantelhardt, 2012), future research could examine the effects of investment support in groups of farms that are more homogeneous. Such research could help developing more accurate recommendations on the design of economic policy aimed at the modernization of agriculture.

\section{Conclusions}

In this research we employed a propensity score matching approach to assess the impact of investment support on labour productivity in Lithuanian family farms. In order to pair treated and control units, we used nearest neighbour matching. We assumed that farms ${ }^{\text {' }}$ characteristics in period $t$ affect the probability of participation in investment measures in period $t+1$ and labour productivity in period $t+2$. The research relied on panel data from FADN dataset. The data covered years 2007-2012.

The period of 2007-2012 marked an increase in investment in Lithuanian family farms. However, despite these changes, family farms in Lithuania lagged behind those in the developed countries (such as Denmark and Germany) in terms of key investment indicators. Cross-country differences in labour productivity were also observed. Indeed, total output per AWU in Lithuania amounted to 18777 EUR/AWU in 2007-2012, whereas in Denmark and Germany it reached 219197 EUR/AWU and 96877 EUR/AWU, respectively.

Propensity score matching analysis showed no statistically significant effect of investment support on labour productivity in Lithuanian family farms. On the one hand, this can be explained by the limitations of the methodology used (e.g., too short post-intervention period). On the other hand, however, these results may be a sign of over-investment and inefficient use of capital. Further studies are therefore needed to clarify this issue and provide more accurate recommendations on the design of economic policy aimed at the modernization of agriculture. 
INTERDISCIPLINARY APPROACH TO ECONOMICS AND SOCIOLOGY

\section{References}

Bartova, L., \& Hurnakova, J. (2016). Estimation of farm investment support effects: a counterfactual approach. Retrieved August 6, 2018, from http://fhi.sk/files/katedry/kove/ssov/VKOXVIII/Zbornik2016.pdf\#page=19

Buysse, J., Verspecht, A., \& van Huylenbroeck, G. (2011). Assessing the impact of the EU Common Agricultural Policy pillar II support using micro-economic data. Retrieved January 24, 2019, from http://ageconsearch.umn.edu/bitstream/99596/2/buysseverspechtvanhuylenbroeck.pdf

Ciaian, P., Kancs, D. A., \& Michalek, J. (2015). Investment crowding-out: firm-level evidence from Germany. Retrieved October 11, 2018, from https://papers.ssrn.com/sol3/papers.cfm?abstract_id=2634922

Doucha, T., Pechrova, M., Chaloupka, O., \& Medonos, T. (2017). Investment supports to the Czech farms and their expected future under the CAP 2020+. Retrieved January 14, 2019, from https://papers.ssrn.com/sol3/papers.cfm?abstract_id=3102899

European Commission. (2018). FADN Public Database. Retrieved October 23, 2018, from http://ec.europa.eu/agriculture/rica/database/database_en.cfm

Goolsbee, A. (1998). Investment tax incentives, prices, and the supply of capital goods. The Quarterly Journal of Economics, 113(1), 121-148. doi: https://doi.org/10.1162/003355398555540

Guo, S., \& Fraser, M. W. (2015). Propensity score analysis: Statistical methods and applications. Thousand Oaks, CA: Sage.

Hlavsa, T., Hruška, M., \& Turkova, E. (2017). The impact of investment support from the Rural Development Programme of the Czech Republic for 2007-2013 on the economic efficiency of farms. Studies in Agricultural Economics, 119(1), 11-17. doi: https://dx.doi.org/10.7896/j.1014

Huggett, M., \& Ospina, S. (2001). Does productivity growth fall after the adoption of new technology? Journal of Monetary Economics, 48(1), 173-195. doi: https://doi.org/10.1016/S0304-3932(01)00065-4

Kirchweger, S., \& Kantelhardt, J. (2012). Improving farm competitiveness through farminvestment support: a propensity score matching approach. Retrieved December 27, 2018, from https://www.wiso.boku.ac.at/fileadmin/data/H03000/H73000/H73300/pub/2012/2012_

EAAE_Seminar_Kirchweger-Kantelhardt.pdf

Kirchweger, S., Kantelhardt, J., \& Leisch, F. (2015). Impacts of the government-supported investments on the economic farm performance in Austria. Agricultural Economics (Zemědělská Ekonomika), 61(8), 343-355. doi: https://doi.org/10.17221/250/2014AGRICECON

Kollár, B., \& Sojková, Z. (2016). Impact of the Investment Subsidies on the Efficiency of Slovak Farms. Retrieved January 28, 2018, from http://www.opf.slu.cz/uds/konference/sbornik16/pdf/kollar_sojkova.pdf

Kulawik, J. (2016). Dylematy budżetowego wspierania inwestycji rolniczych. Zagadnienia Ekonomiki Rolnej, 2(347), 52-72. DOI: 10.5604/00441600.1203341

Lithuanian Institute of Agrarian Economics. (2018). FADN survey results. Retrieved October 22, 2018, from https://www.laei.lt/index.php?mt=vt_UADT_tyrimas\&straipsnis=482

Medonos, T., Ratinger, T., Hruska, M., \& Spicka, J. (2012). The assessment of the effects of investment support measures of the Rural Development Programmes: the case of the Czech Republic. Agris on-line Papers in Economics and Informatics, 4(4), 35-48.

National Paying Agency. (2019). Statistics of the Rural Development Programme for Lithuania 2007-2013, Retrieved February 11, 2018, from 
https://www.nma.lt/index.php/parama/lietuvos-kaimo-pletros-20072013-mprograma/statistika/8801\#res

Papageorgiou, A. (2015). Agricultural Equipment in Greece: Farm Machinery Management in the Era of Economic Crisis. Agriculture and Agricultural Science Procedia, 7, 198-202. doi: https://doi.org/10.1016/j.aaspro.2015.12.017

Pawłowska, A., \& Bocian, M. (2017). Estymacja wpływu polityki rolnej na wydajność pracy z wykorzystaniem propensity score matching. Warszawa: Instytut Ekonomiki Rolnictwa i Gospodarki Żywnościowej-Państwowy Instytut Badawczy.

Pawłowska, A., Bocian, M., \& Jaroszewska, J. (2018). Evaluation of investment support under Rural Development Programme 2014-2020 - preliminary results for Poland. Retrieved August 22, 2018, from http://ageconsearch.umn.edu/record/271973/files/Pawlowska_Bocian_Jaroszewska.pdf

Pechrova, M. (2012). Contribution of Supports to Modernisation for Enhancing Competitiveness of the Czech Agricultural and Forestry Holdings. Retrieved January 28, 2019, from http://ageconsearch.umn.edu/bitstream/135773/2/Pechrova2.pdf

Power, L. (1998). The missing link: technology, investment, and productivity. Review of $\begin{array}{llll}\text { Economics } & \text { and } & \text { Statistics, } & \text { 300-313. }\end{array}$ https://doi.org/10.1162/003465398557393

Ratinger, T., Medonos, T., \& Hruška, M. (2013). An Assessment of the Differentiated Effects of the Investment Support to Agricultural Modernisation: the Case of the Czech Republic. Agris On-Line Papers in Economics \& Informatics, 5(4), 153-164.

Ratinger, T., Medonos, T., \& Hruška, M. (2015). The empirical assessments of the effects of the investment support to agriculture in the Czech Republic. Retrieved January 29, 2019, from http://ageconsearch.tind.io//bitstream/212242/2/Ratingger.pdf

Ratinger, T., Curtiss, J., Medonos, T., \& Hruška, M. (2018). The Dynamic Effects of Investment Support of the EU Rural Developent Programme on Czech Farms' Structure and Performance. Retrieved September 3, 2018, from http://ageconsearch.umn.edu/record/276043/files/2028.pdf

Rosenbaum, P. R. (2005). Heterogeneity and Causality: Unit Heterogeneity and Design Sensitivity in Observational Studies. The American Statistician, 59(2), 147-152. doi: https://doi.org/10.1198/000313005X42831

Sakellaris, P. (2004). Patterns of plant adjustment. Journal of Monetary Economics, 51(2), 425-450. DOI: 10.1016/j.jmoneco.2003.03.002

Salvioni, C., \& Sciulli, D. (2018). Rural development policy in Italy: the impact of growthoriented measures on farm outcomes. Agricultural Economics (Zemédělská Ekonomika), 64(3), 115-130. DOI: 10.17221/73/2016-AGRICECON

Sass, R. (2017). Efficiency of investments in Polish farms before and after accession to the European Union. Journal of Agribusiness and Rural Development, 2(44), 445-453. DOI: $10.17306 / J . J A R D .2017 .00309$

Strawiński, P. (2014). Propensity score matching. Własności małopróbkowe. Warszawa: Wydawnictwo Uniwersytetu Warszawskiego.

Takács, I. (2014). Change of Labour Productivity on Farms in European Union Member Countries (2004-2011). Roczniki Naukowe Stowarzyszenia Ekonomistów Rolnictwa i Agrobiznesu, 16(2), 287-293.

Travnikar, T., \& Juvančič, L. (2013). Application of spatial econometric approach in the evaluation of rural development policy: the case of measure Modernisation of agricultural holdings. Studies in Agricultural Economics, 115(2), 98-103. DOI: $10.7896 / \mathrm{j} .1307$

Veveris, A. (2014). Investment support and its impact on the economic results of rural farms in different groups. Retrieved January 29, 2019, from 
http://llufb.llu.lv/conference/economic_science_rural/2014/ESRD_34_2014_Production s-154-162.pdf

Wigier, M., Wieliczko, B., \& Forgarasi, J. (2014). Impact of Investment Support on Hungarian and Polish Agriculture. Retrieved January 29, 2019, from http://ageconsearch.umn.edu/bitstream/172973/2/WigierM-WieliczkoB-

FogarasiJ_Impact $\% 20$ of\%20investment $\% 20$ support $\% 20$ on $\% 20$ Hungarian $\% 20$ and $\% 20 \mathrm{P}$ olish\%20agriculture_agecon.pdf 